\title{
Stomatal conductance in mature deciduous forest trees exposed to elevated $\mathrm{CO}_{2}$
}

\author{
Sonja Gisela Keel · Steeve Pepin - Sebastian Leuzinger • \\ Christian Körner
}

Received: 28 March 2006 / Revised: 3 October 2006 / Accepted: 27 October 2006 / Published online: 5 December 2006

(C) Springer-Verlag 2006

\begin{abstract}
Stomatal conductance $\left(g_{\mathrm{s}}\right)$ of mature trees exposed to elevated $\mathrm{CO}_{2}$ concentrations was examined in a diverse deciduous forest stand in NW Switzerland. Measurements of $g_{\mathrm{s}}$ were carried out on upper canopy foliage before noon, over four growing seasons, including an exceptionally dry summer (2003). Across all species reductions in stomatal conductance were smaller than $25 \%$ most likely around $10 \%$, with much variation among species and trees. Given the large heterogeneity in light conditions within a tree crown, this signal was not statistically significant, but the responses within species were surprisingly consistent throughout the study period. Except during a severe drought, stomatal conductance was always lower in trees of Carpinus betulus exposed to elevated $\mathrm{CO}_{2}$ compared to Carpinus trees in ambient air, but the difference was only statistically significant on 2 out of 15 days. In contrast, stomatal responses in Fagus sylvatica and Quercus petraea varied around zero with no consistent trend in relation to $\mathrm{CO}_{2}$ treatment. During the 2003 drought in the third treatment year, the $\mathrm{CO}_{2}$ effect became reversed in Carpinus, resulting in higher $g_{s}$ in trees
\end{abstract}

Communicated by H. Rennenberg

\section{S. G. Keel $(\varangle)$}

Laboratory of Atmospheric Chemistry, Paul Scherrer Institute, $\mathrm{CH}-5232$ Villigen, Switzerland

e-mail: sonja.keel@psi.ch

S. Pepin $\cdot$ S. Leuzinger $\cdot$ C. Körner

Institute of Botany, University of Basel,

Schönbeinstrasse 6,

CH-4056 Basel, Switzerland

Present address:

S. Pepin

Département des sols et de génie agroalimentaire, Université

Laval, Pavillon Paul-Comtois,

Québec (Québec), Canada, G1K 7P4 exposed to elevated $\mathrm{CO}_{2}$ compared to control trees, most likely due to better water supply because of the previous soil water savings. This was supported by less negative predawn leaf water potential in $\mathrm{CO}_{2}$ enriched Carpinus trees, indicating an improved water status. These findings illustrate (1) smaller than expected $\mathrm{CO}_{2}$-effects on stomata of mature deciduous forest trees, and (2) the possibility of soil moisture feedback on canopy water relations under elevated $\mathrm{CO}_{2}$.

Keywords Biodiversity - Drought . Global change $\cdot$ Water relations $\cdot$ Temperate forest

\section{Introduction}

Reduction of stomatal aperture is a common response of plants exposed to elevated $\mathrm{CO}_{2}$ concentrations (Morison and Gifford 1984). In canopies well-coupled to the atmosphere, such reductions in stomatal conductance $\left(g_{\mathrm{s}}\right)$ result in a corresponding decrease in leaf transpiration. Hence, a large number of studies have been carried out during the last few decades to determine the effect of rising atmospheric $\mathrm{CO}_{2}$ on $g_{\mathrm{s}}$ and water consumption of dominant forest tree species (for reviews see Curtis and Wang 1998; Saxe et al. 1998; Medlyn et al. 2001).

Most of the work examining stomatal responses to $\mathrm{CO}_{2}$ in tree species has been confined to seedlings and saplings, with little research on mature forest trees. These experiments have demonstrated that $g_{\mathrm{s}}$ in young woody individual trees is generally reduced in response to elevated $\mathrm{CO}_{2}$ (mean reduction of 21\%, Medlyn et al. 2001). This has led to the prediction that water use in most forest trees will be reduced as the $\mathrm{CO}_{2}$ concentration in the atmosphere increases. Similarly to herbaceous species, the stomatal responses of saplings exposed to elevated $\mathrm{CO}_{2}$ were found to vary among species 
and to be less pronounced under environmental conditions that reduce maximum $g_{\mathrm{s}}$ (e.g., drought, high temperature, high evaporative demand; Heath 1998; Wullschleger et al. 2002). Furthermore, there is now solid evidence that plant responses to $\mathrm{CO}_{2}$ may change with experimental conditions such as the duration of exposure and plant age (Medlyn et al. 2001), soil characteristics (Bucher-Wallin et al. 2000) and biotic interactions (Körner 2002). Conifer species seem to make an exception, as stomata appear less responsive to $\mathrm{CO}_{2}$ enrichment in this group of species (Teskey 1995; Ellsworth 1999). For all these reasons it is unrealistic to predict the long-term water relation responses of mixed forests to rising $\mathrm{CO}_{2}$ concentrations from data obtained in saplings of certain species grown in artificial substrates for a short period of time. These uncertainties have led to a growing consensus that forest tree research must be carried out on mature individuals under natural forest conditions (Körner 1995).

Nevertheless, exploring the effects of elevated $\mathrm{CO}_{2}$ on water relations of tall forest trees has always presented a considerable challenge given the large size and complex structure of their canopy. Hence, investigations conducted on trees growing near natural $\mathrm{CO}_{2}$ springs (Jones et al. 1995; Tognetti et al. 1998, 1999) and experiments performed with branch-bags (Dufrêne et al. 1993; Teskey 1995; Roberntz and Stockfors 1998) have provided most of the data currently available on mature trees. Although branch-bags offer a useful alternative to growth chambers for the investigation of mature trees, there is little, if any, possibility of feedback effects from the soil because only a small portion of the whole crown is exposed to elevated $\mathrm{CO}_{2}$. Based on sap flow measurements carried out in a mature forest in NW Switzerland, Cech et al. (2003) presented evidence that tree responses to elevated $\mathrm{CO}_{2}$ may be influenced by soil moisture feedback. They reported that during a relatively dry period, $\mathrm{CO}_{2}-$ enriched trees showed increased sap flow density compared to control trees. This reverse $\mathrm{CO}_{2}$-effect, where an increased rather than a reduced transpirational flux (and hence, $g_{\mathrm{s}}$ ) was observed in response to elevated $\mathrm{CO}_{2}$, suggests that daily water savings by $\mathrm{CO}_{2}$-enriched trees may have contributed to an improved water status by the time when control trees fell short in soil moisture. These results highlight the importance of large-scale observations, in which coupled plant-soil systems are studied (Wullschleger et al. 2002).

Using free-air $\mathrm{CO}_{2}$ enrichment (FACE) technology, major advances have been made towards a large-scale approach of studying forest trees under more realistic growth conditions (Ellsworth 1999; Wullschleger et al. 2002; Herrick et al. 2004). Yet, for reasons of practicability, long-term field $\mathrm{CO}_{2}$ experiments with trees have mainly been conducted in relatively young (10-20 years) forest plantations with no (or little) natural interspecific competition for light and water. To our knowledge, no large-scale investigation has examined the effect of $\mathrm{CO}_{2}$ enrichment on a natural, diverse for- est. However, a study conducted on Liquidambar styraciflua L. trees emerging through gaps in the Duke Pinus taeda L. forest provides support to the significance of species identity (Herrick et al. 2004). While the stomata of $P$. taeda showed no significant $\mathrm{CO}_{2}$ response (Ellsworth 1999), those of L. styraciflua do showed the response. Given the evidence that stomatal responses to elevated $\mathrm{CO}_{2}$ are speciesspecific, it is essential to account for tree species diversity when investigating the responses of whole forest stands to elevated $\mathrm{CO}_{2}$.

In this paper, we present stomatal data from the first FACE experiment exposing the canopy of mature broad-leaved trees from six different species in a natural temperate forest ecosystem to elevated $\mathrm{CO}_{2}$ concentrations (ca. $540 \mathrm{ppm}$ ). Stomatal conductance was measured in all species on 11 days over the first full growing season of $\mathrm{CO}_{2}$ exposure to test the hypothesis that stomatal aperture is reduced under elevated $\mathrm{CO}_{2}$ and to determine whether $\mathrm{CO}_{2}$ responses are species-specific. Further measurements were carried out during three additional growing seasons in the three dominant species only. Our main objective was to provide realistic experimental data on $g_{\mathrm{s}}$ of adult deciduous trees exposed to $\mathrm{CO}_{2}$ enrichment for model-based predictions on the water consumption of forests in a high $\mathrm{CO}_{2}$ atmosphere.

\section{Material and methods}

Site description

The experiment was conducted in a diverse forest stand located $15 \mathrm{~km}$ south of Basel, Switzerland $\left(47^{\circ} 28^{\prime} \mathrm{N}, 7^{\circ} 30^{\prime} \mathrm{E}\right.$; elevation: $550 \mathrm{~m}$ a.s.1.). The forest is approximately 100 years old with canopy tree heights between 30 and $35 \mathrm{~m}$. The stand has a stem density of 415 trees ha $^{-1}$ (diameter $\geq 10 \mathrm{~cm}$ ), a total basal area of $46 \mathrm{~m}^{2} \mathrm{ha}^{-1}$ and a leaf area index of approximately 5 in the experimental area. It is dominated by Fagus sylvatica L. and Quercus petraea (Matt.) Liebl., with Carpinus betulus L., Tilia platyphyllos Scop., Acer campestre L. and Prunus avium L. present as companion species. In addition, the site has a strong presence of conifers (Abies alba Mill., Picea abies L., Pinus sylvestris L. and Larix decidua Mill.) outside the $\mathrm{CO}_{2}$-enriched area. Among the species included in the experiment, Fagus and Quercus contribute 24 and $18 \%$, respectively, to the total basal area under the crane, whereas the other four species contribute less than $6 \%$.

The climate is a typical humid temperate zone climate, characterized by mild winters and moderately warm summers. During the 4 years study (2001-2003, 2005), the growing season of deciduous trees lasted from the end of April to the end of October (ca. 180 days). Mean January and July temperatures are 2.1 and $19.1^{\circ} \mathrm{C}$. Total annual precipitation 
for the region averages $990 \mathrm{~mm}$, of which two-thirds fall during the growing season. The soil is a silty-loamy rendzina and is characterized by a $15 \mathrm{~cm}$ deep rock-free topsoil and a $15-30 \mathrm{~cm}$ deep rocky subsoil (approximately $40 \%$ of the subsoil volume are stones) underlain by fragmented limestone bedrock. In the upper $10 \mathrm{~cm}$, the soil has a $\mathrm{pH}$ of 5.8 (measured in distilled water extracts).

\section{$\mathrm{CO}_{2}$ enrichment system (web-FACE)}

A 45-m freestanding tower crane equipped with a 30-m jib and a working gondola provided access to 62 dominant trees in an area of about $3000 \mathrm{~m}^{2}$. A group of 14 adult broad-leaved trees (3 Fagus, 4 Quercus, 4 Carpinus, 1 Tilia, 1 Acer and 1 Prunus), covering a canopy area of roughly $550 \mathrm{~m}^{2}$ were selected for $\mathrm{CO}_{2}$ enrichment, whereof one slim individual of Quercus died. Control trees (3 Fagus, 2 Quercus, 2 Carpinus, 2 Tilia, 2 Acer and 1 Prunus) were located in the remaining crane area at sufficient distance from the $\mathrm{CO}_{2}$ release zone (mainly in the SW area of the plot). $\mathrm{CO}_{2}$-enrichment of the forest canopy was achieved by a free-air, pure $\mathrm{CO}_{2}$ release system that consisted of a web of $4 \mathrm{~mm}$ plastic tubes (approximately $0.5 \mathrm{~km}$ per tree) with $0.5 \mathrm{~mm}$ laser punched holes (spaced at 30-cm intervals) emitting pure $\mathrm{CO}_{2}$ into the tree canopy. For a more detailed description, see Pepin and Körner (2002).

Stomatal conductance and meteorological measurements

Stomatal conductance to water vapour $\left(g_{\mathrm{s}}, \mathrm{mmol} \mathrm{m} \mathrm{m}^{-2} \mathrm{~s}^{-1}\right)$ was measured on upper canopy foliage of 13 trees in elevated $\mathrm{CO}_{2}$ (ca. $540 \mathrm{ppm}$ ) and 12 trees in ambient $\mathrm{CO}_{2}$ (ca. 375 ppm) during 11 sunny days in the summer of 2001 (12 June-25 August). In the subsequent years, measurements were restricted to Fagus, Quercus, and Carpinus (26 June, 8 July and 14 August 2002; 24 June, 22 July [all six species measured], 22 August 2003; 18 August 2005). Measurements of $g_{\mathrm{s}}$ were carried out in the morning (8:00-12:00) on three fully sunlit leaves per tree (1-4 trees per treatment and species) using a transient state diffusion porometer (AP4, Delta-T Devices, Cambridge, UK). The sampling procedure on each measurement day was designed to compare treatments under relatively similar weather conditions. Hence, a tree was randomly selected first, and then an individual of the same species but opposite treatment was randomly chosen. This procedure was subsequently extended to the other trees. In the drought summer 2003 (14 August, 20 August) predawn leaf water potential was measured with a pressure chamber (SKPM 1400,Skye Instruments, Powys, U.K.) from the canopy crane gondola on the same species where stomatal conductance was measured.

Occasional parallel studies with a steady-state photosynthesis system (LI-6400, Li-Cor, Lincoln, NE, USA) recalled consistently lower leaf conductances, a difference for which we found no explanation and which we consider intrinsic to the two devices. Since the LI-6400 system is based on measurements of mass flow and gas concentrations, whereas the AP4's conductance data rely on an indirect calibration procedure with pore plates and does not ventilate leaves, we rather trust the absolute LI-6400 readings. A comparison of $g_{\text {s }}$ values by Körner et al. (1979) and results from as study on non-ventilated porometers by Verhoef (1997) point in the same direction. Concurrent measurements performed with the AP4 porometer and the LI-6400 gas exchange system under different environmental conditions indicated that readings from both instruments are linearly related $\left(g_{\mathrm{s}(\mathrm{LI}-6400)}=\right.$ $\left.0.623 \times g_{\mathrm{s}(\mathrm{AP} 4)}-2.09, R^{2}=0.972\right)$. Hence, the difference is systematic and the AP4 produces signals proportional to the LI-6400. Subsequent measurements of $g_{\mathrm{s}}$ were, nonetheless, carried out with the AP4 porometer for its far better suitability for such a canopy survey, in which much of the 'true' precision comes from good coverage of the natural variability. Such canopy coverage requires rapid measurement in many leaves across all trees in a daily course. Perhaps even more importantly, the AP4 readings are so fast that they capture the momentary stomatal status in a leaf, whereas the time it takes to achieve readings with the LI-6400 will incur stomatal responses to conditions in the cuvette. Since we are exploring treatment differences rather than absolute values for their own sake, any systematic error would not affect our analysis.

\section{Environmental data}

Wind speed, photon flux density, rainfall, air temperature and relative humidity were measured above the tree canopy using a weather station located at the top of the crane (anemometer AN1, quantum sensor QS, tipping bucket rain gauge RG1, shielded temperature and relative humidity probe RHA 1 , Delta-T, Cambridge, UK). Measurements were performed every $30 \mathrm{~s}$ (except for wind speed which was measured as wind run) and data were recorded as 10-min means using a data logger (DL3000, Delta-T, Cambridge, UK). Vapour pressure deficit (VPD) was calculated from 10-min averages of relative humidity and air temperature. Soil water content was measured using time domain reflectometry (TDR). Six point probes were buried at approximately $10 \mathrm{~cm}$ depth, two of which in the $\mathrm{CO}_{2}$ enriched area and four in the surrounding control area (ML2x, Delta-T, Cambridge, UK). Three additional probes were installed in 2004 and all probes were recalibrated. In addition, we used three profile probes to determine moisture content between 0 and $90 \mathrm{~cm}$ depth which provided some indication of relative moisture trends in the sub soil (MP-917 and probes PRB-F, Environmental Sensor Inc., Victoria, BC, Canada). 
Data processing and statistical analysis

We analysed mean $g_{\text {s }}$ per tree using a repeated measures analysis of variance (RM-ANOVA) with species and $\mathrm{CO}_{2}$ treatment as fixed factor effects (type I sums of squares, factors in the same order as listed) and time (measurement day or year) as the repeated factor. Our tree sample consisted of 13 treated trees and 12 controls. The unreplicated species Tilia, Acer and Prunus were pooled and treated as 'other' species, hereafter referred to as 'TAP'. To test the effect of elevated $\mathrm{CO}_{2}$ on $g_{s}$ of all six species, a repeated measures ANOVA was carried out for the first year only (2001; in the following years, measurements have been performed on the three dominant species only). To determine whether $\mathrm{CO}_{2}$ effects on $g_{s}$ differed among years, a subsample of the three main species (Carpinus, Fagus, and Quercus) which were measured throughout the 4 years study was analyzed using averages for each tree and year. Furthermore, a RM-ANOVA was computed for each species separately. In the case of dominant species, a seasonal average was calculated for each tree and year, and analysed by a repeated measures ANOVA with treatment as a fixed factor and year as a repeated factor. A similar RM-ANOVA was also carried out for each species and year separately using measurement day as a repeated factor. Additionally, one-way ANOVAs with $\mathrm{CO}_{2}$ treatment as a fixed factor effect were performed for each species and day separately and for all trees together. $\mathrm{CO}_{2}$-induced reductions in stomatal conductance (in \% of $g_{\mathrm{s}}$ under ambient conditions) were calculated for each species and year. A weighted average reduction was calculated for the years with no exceptional weather conditions $(2001,2002$, and 2005) giving the first year a weight of $11 / 15$, the second year a weight of $3 / 15$ and the fifth year a weight of $1 / 15$ based on the different number of measurement days (Fig. 2 "All"). In the case of 'TAP', the overall mean is identical with the first year mean, since no additional data were obtained in subsequent years with no exceptional weather conditions. All statistical analyses were computed using $R$ version 2.0.1 with a level of significance of $P<0.05$.

\section{Results}

\section{Weather conditions}

The years 2001, 2002 and 2005 were characterized by average weather conditions (Table 1), with the exception of a relatively dry period in August 2001 (Fig. 1). In the first 3 years there were only two TDR probes which produced inconsistent differences between the $\mathrm{CO}_{2}$ enriched area and the control area, most likely due to the large spatial heterogeneity of soils. After reinstallation and calibration of the probes in 2004, soil moisture was slightly and consistently
Table 1 Mean air temperature (T), and vapour pressure deficit (VPD) for each measurement day $(8: 00-12: 00)^{\mathrm{a}}$

\begin{tabular}{lll}
\hline Date & $\mathrm{T}\left({ }^{\circ} \mathrm{C}\right)$ & VPD $(\mathrm{hPa})$ \\
\hline 12 June 01 & 12.2 & 5.1 \\
13 June 01 & 15.6 & 6.9 \\
21 June 01 & 18.5 & 11.0 \\
26 June 01 & 21.5 & 12.1 \\
27 June 01 & 23.0 & 12.9 \\
4 July 01 & 19.0 & 9.1 \\
26 July 01 & 21.3 & 9.5 \\
28 July 01 & 22.3 & 7.2 \\
31 July 01 & - & - \\
12 August 01 & 14.7 & 5.8 \\
25 August 01 & 22.2 & 7.8 \\
26 June 02 & 18.1 & 7.6 \\
8 July 02 & 20.8 & 8.9 \\
14 August 02 & 16.8 & 5.7 \\
24 June 03 & 23.4 & 12.6 \\
22 July 03 & 22.0 & 10.4 \\
22 August 03 & 20.5 & 12.2 \\
18 August 05 & 18.5 & 2.8 \\
\hline
\end{tabular}

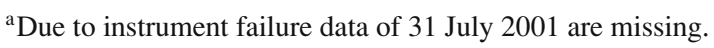

higher in the $\mathrm{CO}_{2}$ enriched area. In the summer of 2003, central Europe experienced a severe drought with precipitation less than half of normal and air temperatures $2-4^{\circ} \mathrm{C}$ higher than the 10-year average (1989-1999). Towards the end of June, soil water content dropped to approximately $10 \%$ (no plant available moisture) in the top $30 \mathrm{~cm}$ measured at our study site and remained at this level throughout July and August (Fig. 1). Similarly low readings were recorded at 60-90 depth with the profile TDR probes during the peak of the drought in August. Hence, during this period, soils were desiccated down to $90 \mathrm{~cm}$ depth of the profile and trees depended on deeper moisture reserves (no ground water table on these slopes).

Stomatal conductance

There was, over all six species, a tendency towards lower stomatal conductance in trees exposed to elevated $\mathrm{CO}_{2}$ compared to trees under ambient $\mathrm{CO}_{2}$ conditions $(-10 \%$, Table 2, Fig. 2). Conductances differed significantly among species and between measurement days leading to a lot of noise in the data set. Furthermore, a significant species $\times$ day effect indicated that different species responded differently to changing weather conditions, which added to the observed variation. Although we found species-specific reductions in $g_{\text {s }}$ ranging from $-4 \%$ in Quercus to $-21 \%$ in Carpinus, the species $\times \mathrm{CO}_{2}$-treatment factor was clearly not significant (Table 2). Only on one single day in 2001 all species showed a slightly reduced $g_{s}$ in elevated $\mathrm{CO}_{2}$ (Fig. 2). To eliminate the large differences in $g_{s}$ among species, the data were standardized with respect to the maximum daily aver- 
Fig. 1 Soil water content at $10 \mathrm{~cm}$ depth in the area exposed to ambient $\mathrm{CO}_{2}$ (A, thin line, $n=2)$ and elevated $\mathrm{CO}_{2}(\mathrm{E}$, thick line, $n=4-7)$, at $60-90 \mathrm{~cm}$ depth (open symbols) and 0-30 cm depth (closed symbols) both in the ambient $\mathrm{CO}_{2}$ area $(n=3)$ and precipitation (bars) during four growing seasons.

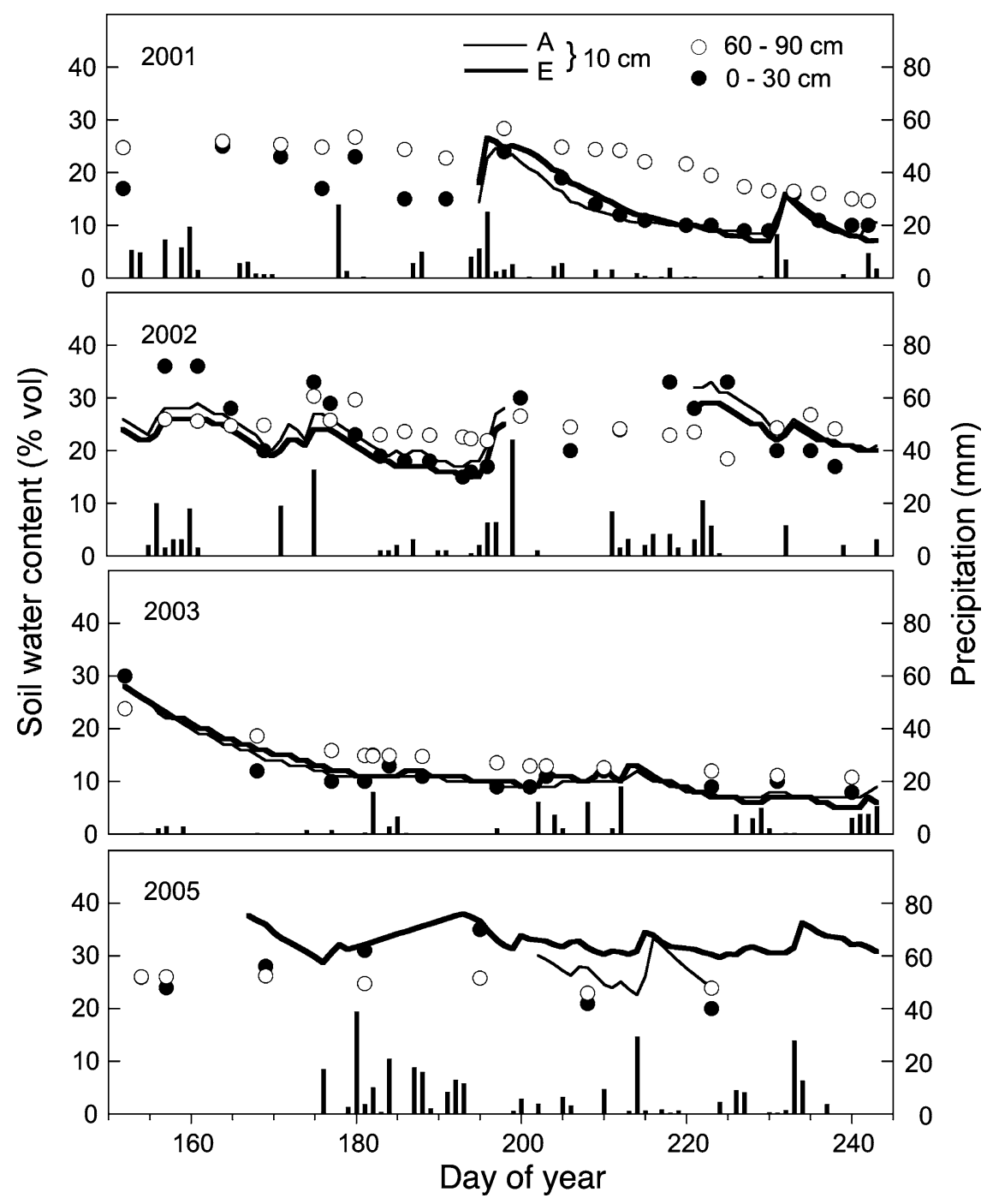

age $g_{s}$ of each tree. This, however, did not lead to a significant $\mathrm{CO}_{2}$ effect either. We calculated the reduction of $g_{\mathrm{s}}$ which could still be detected with the given variation using a power $t$-test with a significance level of 0.05 and a power of 0.8 . A one-sided power $t$-test was used since we did not expect an increase in $g_{s}$ in response to elevated $\mathrm{CO}_{2}$ under regular weather condition. The power test revealed that given the observed variation, a reduction of $25 \%$ in stomatal conductance in $\mathrm{CO}_{2}$-enriched trees would be detectable across all species.

The dominant tree species (Carpinus, Fagus, and Quercus) were sampled over all four study years to examine whether stomatal responses to elevated $\mathrm{CO}_{2}$ persisted in the long term. Results were very similar to those obtained in the first year when all six tree species were considered. There were no significant $\mathrm{CO}_{2}$-effects on $g_{\mathrm{s}}$, but significant differences in $g_{\mathrm{s}}$ among species and years (Table 3 ), the latter being driven by the lower conductances measured in 2003 during the exceptional drought. These differences in $g_{s}$ between
Table 2 Results of repeated measures ANOVA for stomatal conductance of six tree species (Carpinus, Fagus, Quercus, 'TAP' species (Tilia, Acer, Prunus)) exposed to elevated $\mathrm{CO}_{2}$ over 11 measurement days from June to August 2001

\begin{tabular}{llll}
\hline Factor & df & $F$ & $P$ \\
\hline Species & 3 & 3.8 & 0.03 \\
$\mathrm{CO}_{2}$ & 1 & 2.4 & 0.14 \\
Species $\times \mathrm{CO}_{2}$ & 3 & 0.2 & 0.91 \\
Day & 10 & 12.1 & $<0.001$ \\
Species $\times$ Day & 30 & 3.0 & $<0.001$ \\
$\mathrm{CO}_{2} \times$ Day & 10 & 1.0 & 0.47 \\
Species $\times \mathrm{CO}_{2} \times$ Day & 30 & 0.5 & 0.98 \\
\hline
\end{tabular}

years were no longer statistically significant after exclusion of the drought year's data.

Among species, Carpinus showed the largest and most consistent reduction in stomatal conductance in response to $\mathrm{CO}_{2}$ enrichment which however was only statistically significant on two single days in the first experimental year 
Fig. 2 Stomatal conductance $\left(g_{\mathrm{s}}\right.$, mean $\left.\pm \mathrm{SE}\right)$ of upper canopy foliage in six deciduous tree species ( $n=12$ trees) exposed to ambient (A, open bars; ca. $375 \mathrm{ppm}$ ) and elevated $\mathrm{CO}_{2}$ (E, dark bars; ca. 540 ppm) during four growing seasons (8:00-12:00). 'TAP' refers to Tilia, Acer, and Prunus, three species that were pooled because they were not replicated (E, $n=3 ; \mathrm{A}, n=5$ ). The 'All' column refers to average $g_{s}$ for 3 years with no exceptional weather conditions $(2001,2002$, 2005) weighted by measurement days per year. In the bottom panel, 'All trees' refers to six species in the year 2001 and on day 203 in 2003 (E, $n=13$; A, $n=12$ ) and the three main species (Carpinus, Fagus, Quercus) in 2002, 2003 and 2005 (E, $n=10 ; \mathrm{A}, n=7)$.

Percent numbers represent mean $\mathrm{CO}_{2}$ signals $\pm \mathrm{SE}$ across season. The summer of 2003 was exceptionally dry. Note, the AP4 porometer produces somewhat high absolute $g_{s}$ values, which however, does not affect differences between $\mathrm{CO}_{2}$ treatments (see Material and

Methods) ${ }^{(*)} P<0.1$ $* P<0.05 ;{ }^{* *} P<0.01$; ${ }^{* * *} P<0.001$

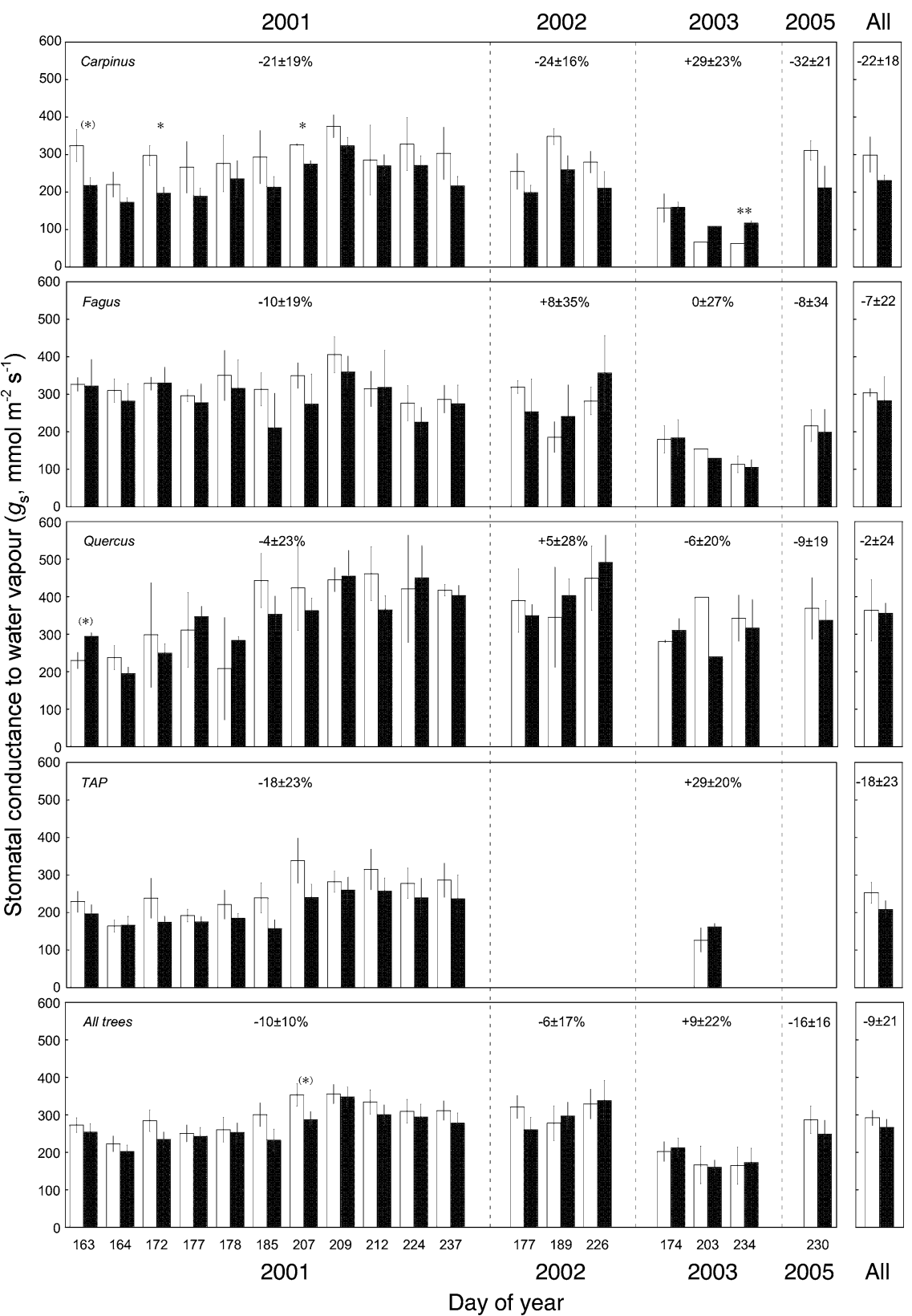

(Fig. 2). Over the four year period the $\mathrm{CO}_{2}$ effect was not significant (Table 4). Test results were also not significant when considering the growing seasons with no extraordinary weather conditions only or each year separately. For the 'TAP' species, there were no significant differences between treatments (test results not shown). Fagus and Quercus showed very small (to negligible) and inconsistent stomatal responses (Fig. 2).

Stomatal responses to elevated $\mathrm{CO}_{2}$ during a severe drought

During a prolonged drought period in the summer of 2003 (Fig. 1), $g_{\mathrm{s}}$ of $\mathrm{CO}_{2}$-enriched trees and control trees were strongly reduced in most species compared to previous years
(Fig. 2). There was, however, considerable variability in stomatal responses to drought among tree species. Mean seasonal $g_{\mathrm{s}}$ at ambient $\mathrm{CO}_{2}$ during the drought year were only slightly reduced in Quercus (6\%) compared to 2001, whereas in Fagus, the 'TAP' species and Carpinus, moderate to pronounced reductions were found $(52-68 \%$; see 'Year'-effect in Table 4).

Towards the end of this severe drought, we observed significantly higher conductances in $\mathrm{CO}_{2}$-enriched Carpinus trees compared to control trees $(P=0.004$, Fig. 2$)$. A trend towards higher $g_{s}$ values under elevated $\mathrm{CO}_{2}$ was also observed in the 'TAP' species. At the same time, predawn leaf water potentials tended to be higher in $\mathrm{CO}_{2}$-enriched $\mathrm{Carpi}$ nus trees $\left(-1.14 \mathrm{MPa}\right.$ in ambient $\mathrm{CO}_{2}$ vs. $-0.91 \mathrm{MPa}$ in 
Table 3 Results of repeated measures ANOVA for stomatal conductance of trees exposed to elevated $\mathrm{CO}_{2}$ of three species (Carpinus, Fagus, and Quercus) during four growing seasons (2001, 2002, 2003, 2005)

\begin{tabular}{llll}
\hline Factor & df & $F$ & $P$ \\
\hline Species & 2 & 6.71 & 0.014 \\
$\mathrm{CO}_{2}$ & 1 & 0.50 & 0.49 \\
Species $\times \mathrm{CO}_{2}$ & 2 & 0.13 & 0.88 \\
Year & 3 & 18.38 & $<0.001$ \\
Species $\times$ Year & 6 & 2.07 & 0.09 \\
$\mathrm{CO}_{2} \times$ Year & 3 & 0.93 & 0.44 \\
Species $\times \mathrm{CO}_{2} \times$ Year & 6 & 0.64 & 0.70 \\
\hline
\end{tabular}

Table 4 Results of repeated measures ANOVA for stomatal conductance of three species exposed to elevated $\mathrm{CO}_{2}$ over four growing season $(2001,2002,2003,2005)$

\begin{tabular}{|c|c|c|c|c|c|c|c|}
\hline \multirow[b]{2}{*}{ Factor } & \multirow[b]{2}{*}{ df } & \multicolumn{2}{|c|}{ Carpinus } & \multicolumn{2}{|c|}{ Fagus } & \multicolumn{2}{|c|}{ Quercus } \\
\hline & & $F$ & $P$ & $F$ & $P$ & $\bar{F}$ & $P$ \\
\hline $\mathrm{CO}_{2}$ & 1 & 3.11 & 0.18 & 0.02 & 0.91 & 0.02 & 0.89 \\
\hline Year & 3 & 7.77 & 0.005 & 12.7 & 0.0005 & 2.73 & 0.11 \\
\hline $\mathrm{CO}_{2} \times$ Year & 3 & 1.58 & 0.25 & 0.34 & 0.80 & 0.20 & 0.90 \\
\hline
\end{tabular}

elevated $\mathrm{CO}_{2}, P=0.053$ ) but not in trees belonging to the 'TAP' species). In Fagus and Quercus, $g_{s}$ was not altered by $\mathrm{CO}_{2}$ enrichment under these dry soil conditions, in line with the data for other years with no extraordinary weather conditions when no significant $\mathrm{CO}_{2}$ effect was detected on $g_{s}$.

\section{Discussion}

This study documents responses of stomatal conductance in a diverse natural forest to elevated $\mathrm{CO}_{2}$. The 4 year data reveal that reductions in conductance in response to $540 \mathrm{ppm} \mathrm{CO}_{2}$ are certainly smaller than $25 \%$. Despite the large number of readings and 4 years of data collection, we were unable to demonstrate the occurrence of a statistically significant reduction of stomatal conductance and only found a tendency towards reduced $g_{\mathrm{s}}$ of around $10 \%$ when averaged across all species and trees. As can be seen in Fig. 2 Carpinus and the 'TAP' species (Tilia, Acer and Prunus) consistently show more pronounced reductions of $g_{\mathrm{s}}$ compared to other species which is in full agreement with sap flow data from the same trees in 2001 (Cech et al. 2003).

The size of the responses seen in Carpinus and the 'TAP' species over the 4 years, though not significant, are well in line with the mean $21 \%$ reduction reported by Medlyn et al. (2001) using a meta analysis for long-term experiments carried out in the field and are also consistent with measurements carried out on Liquidambar styraciflua in two FACE experiments ( $-24 \%$, Gunderson et al. 2002; $-28 \%$, Herrick et al. 2004). The responses in Fagus and Quercus were much smaller and less uniform, hence $\mathrm{CO}_{2}$ effects at the leaf level are much less likely even if we had more trees. In line with our findings Dufrêne et al. (1993), using branchbags in mature Fagus, also found no $\mathrm{CO}_{2}$-effect on $g_{\mathrm{s}}$ in this most common European deciduous tree species. A number of full grown tree species, the noteworthy conifers, also have shown no stomatal response to elevated $\mathrm{CO}_{2}$ (Teskey 1995; Ellsworth 1999).

Our data therefore support that stomatal responses to elevated $\mathrm{CO}_{2}$ are most likely species-specific. The presence or absence of a certain species in a catchment would thus have hydrological consequences. Our data illustrate the risk of drawing general conclusions from a single species' response. In this sense, our results match studies conducted on saplings and potted trees, which also reported great species specificity in stomatal responses to $\mathrm{CO}_{2}$ (Picon et al. 1996; Heath 1998).

The study of $g_{\mathrm{s}}$ in this natural, highly diverse, mature forest exposed to elevated $\mathrm{CO}_{2}$ suffered from the common experimental and analytical difficulties when realistic test conditions come into play (Körner 2001). To comply with the height requirement of the study trees (between 30 and $35 \mathrm{~m}$ ) and the complex structure of the canopy, a new $\mathrm{CO}_{2}$ enrichment system was designed (web-FACE, Pepin and Körner 2002). However, the need of a canopy crane did not permit randomization of the treatment units (it would require several cranes) and therefore, we employed a detailed investigation of a priori differences in physiology and morphology between control trees and those later exposed to elevate $\mathrm{CO}_{2}$. The analysis performed by Cech et al. (2003) revealed no systematic differences between the two groups of trees, hence the prerequisites for the experiment were fulfilled. Given the stature of the forest, the large size of the $\mathrm{CO}_{2}$-enriched area exerted a further constraint, namely that not all species could be measured at the same time despite rapid crane operation. On the other hand, the area was still not large enough to permit replication in both treatments to a desirable extent. One way to handle this was to consider the $\mathrm{CO}_{2}$ response of 'trees' only, irrespective of species (13 treated trees and 12 control trees). We performed such tests, but these revealed no significant $\mathrm{CO}_{2}$ effect either, possibly due to the large variation in absolute $g_{\mathrm{s}}$ among species (at full stomatal opening $g_{\mathrm{s}}$ in Quercus is roughly 2 times that of the other species).

Despite these inevitable problems, it is still remarkable that the trend towards reduced stomatal conductance in these deciduous tree species exposed to elevated $\mathrm{CO}_{2}$ was sustained throughout the summers of 2001, 2002 and 2005 (with no exceptional weather conditions as opposed to 2003). This is in agreement with earlier studies which have shown small but consistent responses in $g_{\mathrm{s}}$ of Liquidambar styraciflua trees over 3-4 years of $\mathrm{CO}_{2}$ enrichment (Gunderson et al. 2002; Herrick et al. 2004). Bearing in mind that trees in this study are of considerable age, height, and size, the consistency of the responses over several years (particularly in 
Carpinus) leads to our confidence in the data, although differences were rarely statistically significant. Very good correspondence between these leaf level stomatal conductance data and sap flow density carried out on the same trees in 2001 adds to this confidence. Reductions in mean daily sap flow density of $\mathrm{CO}_{2}$-enriched trees averaged approximately $11 \%$ across all days of the growing season in 2001 (Cech et al. 2003), a value close to the non significant overall $10 \%$ reduction in $g_{\mathrm{s}}$ (mean of all six tree species) reported here for the first year, although the stomatal signal does not include a boundary layer component. Furthermore, the same species were found to be more responsive to elevated $\mathrm{CO}_{2}$ (Carpinus and the 'TAP' species).

In plant systems with high stomatal control over transpiration, $\mathrm{CO}_{2}$-induced reductions in $g_{\mathrm{s}}$ can lead to a decrease in water consumption and result in higher soil moisture content (Hungate et al. 2002), which was also found at our study site (Leuzinger 2006). During a period of relatively high evaporative demand and decreasing soil water content in 2001 summer, Cech et al. (2003) observed greater sap flow density in $\mathrm{CO}_{2}$-enriched trees than in control trees. $\mathrm{Al}$ though the differences in sap flow density between the two groups of trees were not statistically significant, treatment differences increased over time, providing support to the hypothesis that soil moisture savings in the $\mathrm{CO}_{2}$-enriched area could reverse the effect of elevated $\mathrm{CO}_{2}$ on stomatal conductance and transpiration. More recent soil moisture data from our site confirm this pattern of a reverse effect of soil drying during prolonged rainless periods (Leuzinger 2006). Based on these findings we expected similar soil moisture feedback to appear during the drought conditions of summer 2003 and indeed, we did observe such a reversal of $\mathrm{CO}_{2}$ effects on $g_{\mathrm{s}}$ of Carpinus and a tendency in this direction in the 'TAP' species. Less negative predawn leaf water potentials in Carpinus under elevated $\mathrm{CO}_{2}$ and drought adds a piece of evidence that water status in this species was improved compared to control trees and indicates that this species was more sensitive to $\mathrm{CO}_{2}$ enrichment than the other study species.

These results suggest that small, $\mathrm{CO}_{2}$-induced decreases in $g_{\mathrm{s}}$ at the leaf level which are hardly measurable, are sufficient to translate into a cumulative soil water enrichment in the area exposed to elevated $\mathrm{CO}_{2}$. There are insufficient data for the rocky subsoil to verify this for roots at greater depth, but a higher predawn leaf water potential under elevated $\mathrm{CO}_{2}$ and drought suggests water savings throughout all rooted soil horizons (Leuzinger et al. 2005). During the summer drought of 2003, these water savings must have occurred at much deeper soil layers, because soil moisture dropped to $10 \%$ at 60-90 cm depth (corresponding to air dry soil moisture). Manual TDR readings at high spatial frequency in 2002 confirmed that soil water content at approximately $10 \mathrm{~cm}$ was significantly increased in the $\mathrm{CO}_{2}$-enriched area (Cech et al.
2003). Yet, during the extreme summer drought, this method was not applicable since the top soil was completely dry.

During the severe drought of summer 2003, $g_{\mathrm{s}}$ decreased considerably in all investigated species, with the exception of Quercus (a deep rooted, drought-tolerant genus which might have access to soil moisture at greater depth, Becker 1990; Epron and Dreyer 1993; Leuschner et al. 2001). Again, the results matched sap flow measurements showing nearly constant sap flow density in Quercus throughout the summer months, whereas in Carpinus and Fagus sap flow density decreased to half of the early summer maxima (Leuzinger et al. 2005).

In conclusion, we showed that stomatal responses to elevated $\mathrm{CO}_{2}$ in these mature forest trees are certainly smaller than $25 \%$, most likely in the range of about $10 \%$ across species. Globally, even small $\mathrm{CO}_{2}$-driven reductions in stomatal conductance could have a significant impact on the water balance. Using gas exchange theory only, Gedney et al. (2006) speculated that such trends influenced run-off in the twentieth century in a continental specific way. But based on our and other field data (those for conifers in particular) and accounting for atmospheric feedback, we believe that theory based signals are likely to overestimate actual effects substantially. However in the long run, such species specific differences may lead to a change in species abundance driven by soil moisture (and nutrient) effects. Our results clearly demonstrate the need to account for biodiversity and both soil moisture and atmospheric humidity feedback on $\mathrm{CO}_{2}$ responses of stomata in order to arrive at a realistic picture of the hydrological and biological consequences of ongoing atmospheric $\mathrm{CO}_{2}$-enrichment.

Acknowledgements We thank Erwin Amstutz and Olivier Bignucolo for crane operations and on site support. The $\mathrm{CO}_{2}$-enrichment experiment was funded by the Swiss National Science Foundation Projects No. 3100-059769.99, No. 3100-067775.02, No. 5005-65755 (Swiss NCCR Climate) and the Swiss Canopy Crane by the Swiss Agency for the Environment, Forest and Landscape. We thank two anonymous reviewers for helpful suggestions on the manuscript.

\section{References}

Becker MLG (1990) Le point sur l'écologie comparée du chêne sessile et du chêne pédonculé. Revue Forestière Française 42:148-154

Bucher-Wallin IK, Sonnleitner MA, Egli P, Günthardt-Goerg MS, Tarjan D, Schulin R, Bucher JB (2000) Effects of elevated $\mathrm{CO}_{2}$, increased nitrogen deposition and soil on evapotranspiration and water use efficiency of spruce-beech model ecosystems. PhytonAnnales Rei Botanicae 40:49-60

Cech PG, Pepin S, Körner C (2003) Elevated $\mathrm{CO}_{2}$ reduces sap flux in mature deciduous forest trees. Oecologia 137:258-268

Curtis PS, Wang XZ (1998) A meta-analysis of elevated $\mathrm{CO}_{2}$ effects on woody plant mass, form, and physiology. Oecologia 113:299313 
Dufrêne E, Pontailler JY, Saugier B (1993) A branch bag technique for simultaneous $\mathrm{CO}_{2}$ enrichment and assimilation measurements on beech (Fagus sylvatica L.). Plant Cell Environ 16:1131-1138

Ellsworth DS (1999) $\mathrm{CO}_{2}$ enrichment in a maturing pine forest: are $\mathrm{CO}_{2}$ exchange and water status in the canopy affected? Plant Cell Environ 22:461-472

Epron D, Dreyer E (1993) Long-term effects of drought on photosynthesis of adult oak trees Quercus petraea (Matt.) Liebl and Quercus robur $\mathrm{L}$. in a natural stand. New Phytologist 125:381-389

Farquhar GD, Wong SC (1984) An empirical-model of stomatal conductance. Aust J Plant Physiol 11:191-209

Gedney N, Cox PM, Betts RA, Boucher O, Huntingford C, Stott PA (2006) Detection of a direct carbon dioxide effect in continental river runoff records. Nature 439:835-838

Gunderson CA, Sholtis JD, Wullschleger SD, Tissue DT, Hanson PJ, Norby RJ (2002) Environmental and stomatal control of photosynthetic enhancement in the canopy of a sweetgum (Liquidambar styraciflua $\mathrm{L}$.) plantation during 3 years of $\mathrm{CO}_{2}$ enrichment. Plant Cell Environ 25:379-393

Heath J (1998) Stomata of trees growing in $\mathrm{CO}_{2}$-enriched air show reduced sensitivity to vapour pressure deficit and drought. Plant Cell Environ 21:1077-1088

Herrick JD, Maherali H, Thomas RB (2004) Reduced stomatal conductance in sweetgum (Liquidambar styraciflua) sustained over long-term $\mathrm{CO}_{2}$ enrichment. New Phytologist 162:387-396

Hungate BA, Reichstein M, Dijkstra P, Johnson D, Hymus G, Tenhunen JD, Hinkle CR, Drake BG (2002) Evapotranspiration and soil water content in a scrub-oak woodland under carbon dioxide enrichment. Global Change Biol 8:289-298

Jones MB, Brown JC, Raschi A, Miglietta F (1995) The effects on Arbutus unedo L. of long-term exposure to elevated $\mathrm{CO}_{2}$. Global Change Biol 1:295-302

Körner C (1995) Towards a better experimental basis for upscaling plant responses to elevated $\mathrm{CO}_{2}$ and climate warming. Plant Cell and Environ 18:1101-1110

Körner C (2001) Experimental plant ecology: some lessons from global change research. In: Press MC, Huntly NJ, Levin S (eds) Ecology: Achievement and challenge. Blackwell Science, Oxford, UK, pp 227-247

Körner C (2002) $\mathrm{CO}_{2}$ Enrichment: Effects on Ecosystems. In: Munn T (ed) Encyclopedia of global environmental change, vol 2. Wiley, Chichester, pp 215-224

Körner C, Scheel JA, Bauer H (1979) Maximum leaf diffusive conductance in vascular plants. Photosynthetica 13:45-82

Leuschner C, Hertel D, Coners H, Büttner V (2001) Root competition between beech and oak: a hypothesis. Oecologia 126:276-284
Leuzinger S (2006) Water relations in deciduous forest trees under elevated $\mathrm{CO}_{2} . \mathrm{PhD}$ thesis. University of Basel

Leuzinger S, Zotz G, Asshoff R, Körner C (2005) Responses of deciduous forest trees to severe drought in Central Europe. Tree Physiol 25:641-650

Medlyn BE, Barton CVM, Broadmeadow MSJ, Ceulemans R, De Angelis P, Forstreuter M, Freeman M, Jackson SB, Kellomäki S, Laitat E, Rey A, Roberntz P, Sigurdsson BD, Strassemeyer J, Wang K, Curtis PS, Jarvis PG (2001) Stomatal conductance of forest species after long-term exposure to elevated $\mathrm{CO}_{2}$ concentration: a synthesis. New Phytologist 149:247-264

Morison JIL, Gifford RM (1984) Plant-growth and water-use with limited water-supply in high $\mathrm{CO}_{2}$ concentrations. 1 . Leaf-area, wateruse and transpiration. Aust J Plant Physiol 11:361-374

Pepin S, Körner C (2002) Web-FACE: a new canopy free-air $\mathrm{CO}_{2}$ enrichment system for tall trees in mature forests. Oecologia 133:1-9

Picon C, Guehl JM, Ferhi A (1996) Leaf gas exchange and carbon isotope composition responses to drought in a drought-avoiding (Pinus pinaster) and a drought- tolerant (Quercus petraea) species under present and elevated atmospheric $\mathrm{CO}_{2}$ concentrations. Plant Cell and Environ 19:182-190

Roberntz P, Stockfors J (1998) Effects of elevated $\mathrm{CO}_{2}$ concentration and nutrition on net photosynthesis, stomatal conductance and needle respiration of field-grown Norway spruce trees. Tree Physiol 18:233-241

Saxe H, Ellsworth DS, Heath J (1998) Tree and forest functioning in an enriched $\mathrm{CO}_{2}$ atmosphere. New Phytologist 139:395436

Teskey RO (1995) A field study of the effects of elevated $\mathrm{CO}_{2}$ on carbon assimilation, stomatal conductance and leaf and branch growth of Pinus taeda trees. Plant Cell Environ 18:565-573

Tognetti R, Longobucco A, Miglietta F, Raschi A (1998) Transpiration and stomatal behaviour of Quercus ilex plants during the summer in a Mediterranean carbon dioxide spring. Plant Cell Environ 21:613-622

Tognetti R, Longobucco A, Miglietta F, Raschi A (1999) Water relations, stomatal response and transpiration of Quercus pubescens trees during summer in a Mediterranean carbon dioxide spring. Tree Physiol 19:261-270

Verhoef A (1997) The effect of temperature differences between porometer head and leaf surface on stomatal conductance measurements. Plant Cell Environ 20:641-646

Wullschleger SD, Gunderson CA, Hanson PJ, Wilson KB, Norby RJ (2002) Sensitivity of stomatal and canopy conductance to elevated $\mathrm{CO}_{2}$ concentration-interacting variables and perspectives of scale. New Phytologist 153:485-496 